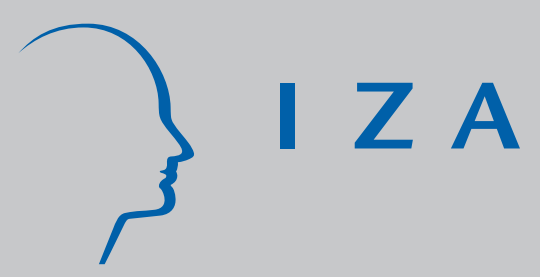

IZA DP No. 176

Industrial Relations and the Wage Differentials between Skilled and Unskilled Blue-Collar Workers within Establishments: An Empirical Analysis with Data of Manufacturing Firms

Olaf Hübler

Wolfgang Meyer

J uly 2000 


\title{
Industrial Relations and the Wage Differentials between Skilled and Unskilled Blue-Collar Workers within Establishments: An Empirical Analysis with Data of Manufacturing Firms
}

\author{
Olaf Hübler \\ Institute of Quantitative Economic Research, University of Hannover and IZA, Bonn \\ Wolfgang Meyer \\ Institute of Economics, University of Hannover \\ Discussion Paper No. 176 \\ July 2000 \\ IZA \\ P.O. Box 7240 \\ D-53072 Bonn \\ Germany \\ Tel.: +49-228-3894-0 \\ Fax: +49-228-3894-210 \\ Email: iza@iza.org
}

This Discussion Paper is issued within the framework of IZA's research area The Future of Work. Any opinions expressed here are those of the author(s) and not those of the institute. Research disseminated by IZA may include views on policy, but the institute itself takes no institutional policy positions.

The Institute for the Study of Labor (IZA) in Bonn is a local and virtual international research center and a place of communication between science, politics and business. IZA is an independent, nonprofit limited liability company (Gesellschaft mit beschränkter Haftung) supported by the Deutsche Post AG. The center is associated with the University of Bonn and offers a stimulating research environment through its research networks, research support, and visitors and doctoral programs. IZA engages in (i) original and internationally competitive research in all fields of labor economics, (ii) development of policy concepts, and (iii) dissemination of research results and concepts to the interested public. The current research program deals with (1) mobility and flexibility of labor markets, (2) internationalization of labor markets and European integration, (3) the welfare state and labor markets, (4) labor markets in transition, (5) the future of work, (6) project evaluation and (7) general labor economics.

IZA Discussion Papers often represent preliminary work and are circulated to encourage discussion. Citation of such a paper should account for its provisional character. 
IZA Discussion Paper No. 176

July 2000

\section{ABSTRACT \\ Industrial Relations and the Wage Differentials between \\ Skilled and Unskilled Blue-Collar Workers within Establishments: An Empirical Analysis with Data of Manufacturing Firms*}

Increased wage inequality between skilled and unskilled workers is a stylized fact, which can be observed in many developed countries. Among the explanations advanced for this phenomenon is the increasing globalization, a skill-biased technical progress, restructuring of the firms, and last but not least, a decreasing importance of industrial relations institutions. In the paper, we investigate in a three-step procedure with firms' data whether the latter determinant is influential. We control for the other relevant explanations and split industrial relations into three components - coverage of collective bargaining, existence of a works council, and union density - within a four-equation model. We find an insignificant influence of the union density. A Works council compresses the wage differentials between skilled and unskilled blue-collar workers while coverage is effective in the opposite direction. The latter two effects nearly offset each other.

JEL Classification: J31, J51

Keywords: Wage differentials, skilled and unskilled labour, union density, works councils, coverage of collective bargaining

Olaf Hübler

Institute of Quantitative Economic Research

University of Hannover

Königsworther Platz 1

30167 Hannover

Germany

Tel.: +495117624794

Fax: +495117623923

Email: huebler@mbox.iqw.uni-hannover.de

\footnotetext{
* We gratefully acknowledge financial support for the Hannover Panel by the Volkswagen-Stiftung and thank Ulrike Schneider for helpful comments.
} 
In the last years, the discussion on wage inequality has intensified in response to recent empirical trends. Especially in the United States and in the United Kingdom real wages have stagnated or declined for unskilled workers, while skilled workers have improved their position. The most commonly cited explanations for this change are the increasing globalization of the economy, skill-biased technical progress and organizational change. These developments caused labour demand to shift against unskilled workers generating the observed decline in the relative wages of this group. Furthermore, a declining influence of unions and changes in the institutional framework are mentioned. However, in Germany and other European countries empirical investigations on the aggregate level find a nearly stable wage structure, but a substantial rise in structural unemployment. Some economists hold wage rigidities responsible for this tendency (Siebert 1997). But the fact that unskilled unemployment in Germany is similar to that in the United States and lower than in the United Kingdom does not confirm this supposal. Therefore, other economists (Nickell, Bell 1996, Freeman, Schettkat 1999) argue that the German education system produces a more compressed distribution of human capital. However, the compression of skills explains only a modest proportion of the difference in the skilled-unskilled wage differential between Germany and the US.

We believe that in order to learn more about the actual wage differences we have to go beyond aggregate level studies and turn to the analysis of firm's data. Particular attention should be devoted to differences within establishments. Even if flexibility and wage dispersion appear to be weak on the macroeconomic level enormous differences may still prevail between and within establishments. Some firms are flexible and have adjusted to the necessities of globalized economies while others are extremely inflexible. In this case, policy interventions, which affect all enterprises in the same way, are inefficient. To this point, we know only little about wage inequality within and between firms. The intention of this paper is to bring some light into this darkness. Our investigation focuses on the impact of industrial relations on firms' wage structures given that industrial relations are more important in Germany than in other countries.

The paper is organized as follows. In section 2, we discuss some theoretical arguments, in which way industrial relations may affect the firm's internal wage structures. 
Section 3 briefly reviews existing empirical evidence, followed by a presentation of our own analysis in section 4 . We first provide some descriptive statistics and then expose results of a three-step multivariate analysis including corrected IV estimates, principal component analysis and determination of a wage differential function. In the final section, we summarize our results.

\section{Theoretical framework}

Industrial relations institutions are frequently discussed under the topic of „unionization“ in the literature. One of the objectives of the unions is redistribution. Usually, they prefer a less dispersed wage structure across as well as within firms. Several explanations can be found for that line of reasoning. Firstly, workers' solidarity requires a relatively uniform wage distribution. The consensus among workers will be jeopardized if wage differences between skilled and unskilled employees are too large. Secondly, unions are political institutions representing membership interests, where particular consideration is given to the median voter. Thus, unions focus on the median wage which usually falls below the average wage and support an adjustment of the former to the latter. Thirdly, as Lucifora (1999) has emphasized, given the potential arbitrariness in measuring individual productivity, riskadverse workers prefer a narrow wage distribution. Unions will take account of these preferences in their objective functions.

Unions can approach their goal of compressing pay differentials by way of standardizing the wage structure, especially by establishing wage groups for specific tasks and qualifications. Then, the wages of the groups at the lower end of the distribution are raised relatively to the other or the lowest wage group is disestablished altogether. Additionally, the unions may bargain for a hard core of wage increase ("Sockel") in the yearly wage rounds, i. e. a uniform increase for all groups. If they successfully advance this claim, a diminished wage dispersion will result.

Often, the impact of unionization on the wage structure is considered to be connected with trade union density. Within the institutional setting of Germany, however, this may be misleading, since collective agreements are not exclusively applied to union members. Coverage (Tarifbindung) is the more appropriate phenomenon, which is given for all member firms of an employer's association and for enterprises signing a single employer contract. Looking at the relationship between coverage and wage differentials, we have also to take objectives and behaviours of employers into account. In principle, coverage by collective bargaining is an instrument to stabilize employment and the wage structure. Employers and 
employees are usually interested in stable contracts. Workers are risk-adverse and firms favour stability because it simplifies planning and thus decision making under uncertainty. Notwithstanding, situations do exist in which adjustments are necessary and more important than stability. Firms in particular need flexibility and seek to complement „Tarifbindung“ (coverage) with measures that permit the necessary adjustments. One possibility is to implement a wide effective wage structure by a strong wage drift or by using the whole range of negotiated wage groups. Flexibility and adjustment follow by selective hiring and firing.

Decentralized wage bargaining allows a better adjustment of the wage structure to the market requirements. Firms that are not covered by a collective bargaining agreement can adjust by changing the wage level and use the advantages of small wage differentials, especially in the case of teamwork. In a recession, unskilled workers will be laid off while the wage of skilled workers will be reduced. Insider power avoids dismissals of skilled workers. The same firms experience stronger and faster wage increases during an economic recovery. Furthermore, these establishments may adjust by training of unskilled workers if the productivity gap between skilled and unskilled workers exceeds the respective wage gap, as Pischke (1998) has stressed. As firms without „Tarifbindung“ are on average more successful and can fund training measures more easily, this behaviour seems more likely.

Freeman and Medoff (1984) stress that a trade union is a vehicle for collective voice that is, for providing the work force with a mean of communicating with management. But in Germany, works councils instead of the unions seem to express the collective voice, aggregating workers' preferences and transmitting them to the management. A works council offers the prospect of an improvement in the joint surplus of the enterprise via processes of information, exchange, consultation, and participation (Freeman, Lazear 1995). Frequently, the council negotiates works agreements supplementing wages bargained at industry levels. Wage drift is systematically higher in works council regimes. The distributional conflict is a factor that will always interfere with the ability of the works councils to achieve the benefits of participation. Workers' share of the surplus increases with the absolute surplus while profits decline relatively. Profits may also decline in absolute terms because knowledge and involvement constitute power. It is however not obvious whether productivity effects dominate the profit effects.

Management's use of the works councils as a communicator to workers about the state of nature can set an incentive for effort on the part of workers. Consultations allow new solutions. Codetermination provides workers with more security and, therefore, encourages workers to consider the firm's objectives. Works councils also help to restrain influence 
activities. They can convince the employees that co-operation among the workers and with the management strengthens the employee's position and increases their earnings. This results in a higher effort, less shirking and less fluctuation, a lower degree of absenteeism and a higher investment in specific human capital. If works councils have also partial control over the management's decisions, we can expect that the latter will be improved. Inefficiencies within the firms and the risk of opportunistic management behaviour at the cost of the employees may be reduced. Altogether, the voice function of works councils can explain a positive correlation between the existence of such councils and the wage level. In addition, redistribution between employers and employees may result via rent sharing.

If the productivity of unskilled workers is not affected by the activities of works councils to the same extent as the productivity of their skilled colleagues wage differentials may also change. On the one hand, we should expect that works councils have more influence on unskilled workers than on skilled workers. The latter have more confidence in their organization while the formers usually work with high effort even without the support of a works council. A depressed wage distribution should follow. On the other hand, works councils are more sensitive than unions to the positive incentive effects of a wide wage spread. If the wage spread increases productivity and enlarges the firm's, surplus it could imply a better net result for all. Although councils are not entitled to determine the wage level, their rights include the assignment to pay grouping. This affects the wage dispersion. The more workers are assigned to one or only few wage groups the lower the wage dispersion.

A further indirect mechanism, which induces a negative relationship between industrial relations institutions and wage differentials, may be the pattern of variable pay schemes. The more variability a payment scheme permits the larger the corresponding wage differentials. Incentives that pertain to individual performance, like piece rates, increase the dispersion of earnings within establishments and undermine conventional wage policy (Freeman 1982). Profit sharing may also enlarge the earnings differentials. But these pay elements are not part of the wage differentials. Unions are usually portrayed as institutions, which struggle against more flexibility and oppose profit sharing. The function of works councils differs a little bit from that of unions. One can argue that the works council can help the management to find the best scheme of payment for the firm. Piece rates should not suffer from managerial arbitrariness. Therefore, the employer and the works council have to find an agreement that determines the premia and piece rates. On the one hand, costs can be saved by these negotiations compared with single agreements. In addition, on the other hand, workers 
confine the works council so that influence activities can be avoided. In a non-co-operative regime piece rates will generate extremely high ongoing costs of influence activities unless employees are confident that employers will not unilaterally implement or change wage rate policies. Employees fear cheating by the employers who could alter the terms of the scheme to the benefit of the firm.

Summarizing the previous arguments, the industrial relations institutions are expected to reduce the skilled-unskilled wage differential though there may be circumstances leading to other outcomes. The industrial relations are characterized by three variables indicating (1) the existence of coverage by collective agreements, (2) works councils and (3) trade union density at the establishment level. The indicators describe partially different and partially joint effects on the wage differential between skilled and unskilled workers.

\section{$3 \quad$ Previous empirical evidence}

Over the past years, literature on the increasing wage inequality based on aggregated data has burgeoned, while studies using individual data are scarce. Industrial relations have commanded little attention. Investigations, which use firm's data and analyze the relationship between wage differentials and industrial relations, are almost completely missing.

Fortin and Lemieux (1997) present some evidence on the role of institutional changes on wage distribution in the United States. Deunionization primarily affects men's wages. Graphs illustrate the wage distribution among unionized and non-unionized workers and show that deunionizations have contributed to the erosion of the middle of the wage distribution. Card (1992) and Freeman (1993) find that deunionization explains a fifth of the increase in male wage inequality from the 1970s to the late 1980s while DiNardo, Fortin and Lemieux (1996) estimate a percentage between 14 and 20 percent. Lucifora (1999) has conducted an international comparison of how labour market institutions affect wage inequality and low pay. Based on aggregated data from 20 OECD countries he finds a negative correlation between union density and the wage differential, measured by the log of the ratio of the topto the floor-decile. Higher union density appears to be associated with lower wage dispersion while no effect is detected for the coverage or the centralization of collective bargaining.

Blau and Kahn (1999) summarize the impact of labour market institutions on wage dispersion from a macroeconomic perspective. According to their result, the overall variance in pay is smaller in countries where unions are more prevalent. They find some general evidence that the degree of centralization of wage-setting institutions tends to be associated 
with lower wage inequality. This is particularly traceable to a greater compression at the bottom of the wage distribution. Flanagan (1999) confirms this outcome, although he mentions that the negative cross-country relationship between the centralization of collective bargaining and wage dispersion weakened somewhat in the early 1990s.

Card's (1996) results from a longitudinal study with CPS data suggest that unions raise wages for workers with lower rather than higher levels of observed skills. In the same vein, based on a sample from NLS over the period 1980-1989, Vella and Verbeek (1998) show within a two-equation model - function of union membership and wage equation - that individuals with characteristics typically associated with lower wages receive larger union premia. Unobserved heterogeneity, which positively contributes to the likelihood of union membership, is associated with higher wages.

Haskel (1999) investigates effects on changes in log relative wages of skilled and unskilled work in UK manufacturing. Using a panel of 80 industries over 1980-1989 he finds among others negative, but insignificant effects of an increase in union density on the wage differential. He argues that imprecision may be due to mismeasurement. Data are not available on the change in the relative unionization of the skilled and unskilled.

German studies using firm's data concentrate on the effects of industrial relations on firms ‘ performance. Among others the influence on the average wage level is determined (FitzRoy, Kraft 1985, Addison, Kraft, Wagner 1993, Meyer 1995, Addison, Schnabel, Wagner 1998, Hübler, König 1998, Jirjahn, Klodt 1999). All of them with the exception of FitzRoy and Kraft confirm that firms with a works council pay significantly higher wages. The effect of firms' being covered by collective bargaining is not so obvious. Meyer (1995) and Jirjahn, Klodt (1999) find insignificant negative effects. If the sample is split into firms with and without „Tarifbindung“, the significant works council effect remains only in the latter. It is however interesting to note that the effect of coverage on the existence of piece rate payment is positive. In firms covered by collective bargaining the existence of a works council increases the probability of piece rate payment. In non-covered firms the influence of works councils can be neglected (Heywood, Hübler, Jirjahn 1998). Fitzenberger (1999) and Kraft (1994) have conducted studies with German industry data, which investigate the effects of unions on wage differentials. The latter does not find that active unions influence the ratio of skilled to unskilled worker's wage. He uses data from 23 industries between 1965 and 1990. The former has more differentiated results. But in the majority of the estimates the union effect is also insignificant, especially in the non-manufacturing sector. In manufacturing 
industries a tendency can be observed that stronger unions with higher density increase the weight of employment and care less about wages for low- and medium-skilled workers.

Also research conducted by Gerlach, Hübler, Meyer (1999), does not support the hypothesis that industrial relations affect wage differentials. Their study uses 1997 firms' data from the state of Lower Saxony and a composite measure for industrial relations, which is determined as a factor of a principal component analysis.

\section{$4 \quad$ Empirical analysis}

\subsection{Data and descriptive results}

Our empirical analysis is based on the Hannover Panel (Brand et al. 1996), which is a samplesurvey of establishments designed as a panel study with four years of coverage (1994 - 1997). The population covered encompasses manufacturing establishments with at least five employees in the first wave and which are located in the German federal state of Lower Saxony (Niedersachsen). The sample is stratified according to establishment size and industry, allowing for establishment-proportional and employee-proportional weighting with results representative of the whole population. The data were collected in face to face interviews with firm owners or top managers by the professional survey and opinion research institute Infratest Sozialforschung. The questionnaires covered various aspects of firm structure, firm behaviour and firm performance with an emphasis on issues relating to personnel. A total of 1025 establishments took part in the first wave of the Hannover Panel (1994). Due to panel mortality, the number of participating firms has diminished in the following years. In the fourth wave (1997), that included a question concerning the wage differential between skilled and unskilled blue-collar workers, 711 establishments still participated.

For the empirical analysis of the skilled-unskilled wage differential an indicator is needed that does not mix wage level and wage structure effects. If, for example, the wages of all employees in a firm are increasing with the same percentage - say 10 percent - due to the works council's acting, then both, the average wage and the standard deviation, also increase with the same percentage. In order to avoid this artificial effect the coefficient of variation or the relative wage span between the highest and the lowest wage per hour should be applied. The Hannover panel includes information about the last item, since respondents were asked:

Can you approximately tell us the difference in percent between the highest effective hourly wage rate of a skilled blue-collar worker and the lowest 
effective hourly wage rate of an unskilled blue-collar worker in your establishment? Temporary workers should not be taken into consideration.

617 firms answered this question consistently. ${ }^{1}$ The wage differential is on average 38.0 percent. The interesting question is now: Does the wage differential correspond to differences in industrial relations?

The first indicator characterizing industrial relations employed in our analysis is coverage. Collective agreements are usually negotiated at the industry level. The contracts are binding for the members of the bargaining parties, i.e. for unionized workers whose employer is either a member of an employers 'organization or signed a single-employer contract. Additionally, experience has shown that in those cases where the employer is not forced by law to apply the negotiated conditions he will frequently do so voluntarily, because of threat effects, equity considerations or in order to save transaction costs. In these cases, the firms often apply only parts of the negotiated regulations. Therefore, we have four types of coverage:

1) establishments covered by multi-employer contracts, $\mathrm{N}=344$,

2) establishments covered by single-employer contracts, $\mathrm{N}=52$,

3) establishments voluntarily applying (parts of) multi-employer contracts, $\mathrm{N}=123$,

4) establishments not covered and not applying collective contracts, $\mathrm{N}=98$.

In the following, we concentrate on firms of type one and four. These types are in fact contrasting and should be a suitable basis for an analysis of the impact of coverage while the other two types are hybrid. This is straightforward for firms applying contracts voluntarily, but it may also be true for single-employer bargaining: Decentralized bargaining at the enterprise level allows to have regard to the particular situation of the company, as is the case with non-coverage.

The other central element of industrial relations in Germany concerns the codetermination system. In firms with five or more employees a works council may be elected by the work force (Addison, Schnabel, Wagner 1997). Since this is exactly the minimum size for firms to be selected into our sample, in principal, every establishment could have a works council. However, Table 1 shows in the upper part that in only two thirds of the firms' employees make use of this opportunity. As an additional indicator of the industrial relations,

\footnotetext{
${ }^{1} 9$ Firms without a production department were discarded from the analysis, since the question focused on the wage differential in the production.
} 
the trade union density at establishment level is displayed in the table. Density is rather low in firms without a works council and without coverage and rather high in the opposite cases.

The last two columns of Table 1 give first information about the variation in the skilled-unskilled wage differential according to the existence or non-existence of the aforementioned industrial relation institutions. In establishments covered by collective agreements or provided with a works council, the wage differential is higher than in their counterparts without such institutions. However, the difference is statistically significant in one case only (comparison of type $\mathrm{C}$ with $\mathrm{D}$ ). At first sight, the basic hypothesis that industrial relations institutions reduce the skilled-unskilled wage differential seems not to be corroborated by the data.

Table 1: Industrial relations, firm size and skilled-unskilled wage differential within manufacturing establishments in Lower Saxony $1997^{\mathrm{a}}, \mathrm{N}=442^{\mathrm{b}}$

\begin{tabular}{|c|c|c|c|c|c|c|c|}
\hline Type & $\begin{array}{c}\text { Establishme } \\
\text { covered by } \\
\text { multi-employer } \\
\text { contracts } \\
\end{array}$ & $\begin{array}{l}\text { nts } \\
\text { with a } \\
\text { works } \\
\text { council } \\
\end{array}$ & $\begin{array}{c}\text { Share in } \\
\text { the sample } \\
\text { in } \%\end{array}$ & $\begin{array}{c}\text { Trade } \\
\text { union } \\
\text { density } \\
\text { in } \% \\
\end{array}$ & $\begin{array}{c}\text { Average } \\
\text { number of } \\
\text { employees } \\
\mathrm{n} \\
\end{array}$ & $\begin{array}{l}\text { Wage } \\
\text { differen } \\
\text { tial } \\
\text { in } \% \\
\end{array}$ & $\begin{array}{c}\mid t \text {-test } \mid \text { on } \\
\text { differences } \\
\text { in wage } \\
\text { differential } \\
\end{array}$ \\
\hline A & No & - & 22.2 & 12.2 & 75.1 & 35.1 & \\
\hline B & Yes & - & 77.8 & 41.6 & 180.8 & 38.6 & $\mathrm{AB} \quad 0.99$ \\
\hline $\mathrm{C}$ & - & No & 35.4 & 4.0 & 40.7 & 33.0 & \\
\hline $\mathrm{D}$ & - & Yes & 64.6 & 54.3 & 218.3 & 40.0 & $\mathrm{CD} 2.15^{* *}$ \\
\hline $\mathrm{E}$ & No & No & 15.8 & 1.9 & 41.6 & 31.2 & \\
\hline $\mathrm{F}$ & Yes & No & 19.6 & 5.7 & 40.1 & 34.5 & EF $\quad 0.70$ \\
\hline $\mathrm{G}$ & No & Yes & 6.4 & 42.7 & 148.8 & 39.1 & EG 1.01 \\
\hline $\mathrm{H}$ & Yes & Yes & 58.3 & 55.3 & 225.8 & 40.1 & $\mathrm{EH} 2.13 * *$ \\
\hline
\end{tabular}

$* / * * / * * *$ denote significance at the 0.10 / $0.05 / 0.01$ levels, respectively.

${ }^{\text {a }}$ Information concerning the works council is based on Wave 3, which was collected in 1996.

b Because of missing values concerning the items "works council" and "trade union density" the size of the sample is in some cases smaller.

Source: Hannover Panel, Wave 3 and 4.

In the lower part of Table 1, the establishments are grouped with respect to both institutions simultaneously. Type E firms, the one extreme, are defined by the absence of industrial relations institutions, i. e. have neither coverage nor a works council; type $\mathrm{H}$ firms, on the 
contrary, have both. The latter group covers the bulk of the sample. ${ }^{2}$ The other two types are characterized by a single institution, either coverage (F) or works council (G). Again, the data do not confirm the basic hypothesis that the industrial relations institutions dampen wage inequality. The wage differentials of groups $\mathrm{F}$ to $\mathrm{H}$ are higher than in the reference group $\mathrm{E}$. The works council seems to have a greater impact on the differentials than the unions via collective agreements. If the share of union members among the employees reaches some critical level, the workers tend to elect a works council and try to get covered by bargaining. Collective agreements, however, are not only the result of employees' pressure: Small and middle sized firms with only few union members and without a works council apply negotiated contracts to a considerable extent, too.

The results presented above, however, may be distorted by a firm size bias. One should expect that large firms have on average a very differentiated workplace structure which requires both - at least some - low skilled workers on the one hand and very high skilled on the other hand. A wide wage differential should hence prevail in large firms. Small and middle-sized firms, by contrast, will often have only one category of workplaces, either skilled or unskilled, leading to a smaller difference between the highest and the lowest wage. Table 1 clearly shows a positive correlation between firm size and the appearance of industrial relations institutions and this is well documented in the literature (Addison, Schnabel, Wagner 1997; Bellmann, Kohaut, Schnabel 1999). Therefore, the firm size may be the factual driving force of the observed differences in the wage differentials. Apparently, a multivariate analysis is necessary to control for that possibility.

\subsection{Methods and results of the multivariate analysis}

A multiple regression model can be used to study the impact of industrial relations on the skilled-unskilled wage differential with controls for other determinants of wage dispersion. These may be variables affecting the workplace structure and the marginal productivity of the employees working at the highest and lowest skilled position. Potentially important variables are grouped into the following conceptual areas: Globalization of the economy, factor biased technical progress and restructuring of the enterprise (Snower 1999). For the purpose of empirical investigations, suitable indicators need to be developed for these theoretical constructs. Numerous variables exist which may be included in regression models to describe

\footnotetext{
${ }^{2}$ For the underlying population the share of firms with coverage and a works council is considerably lower, since we have an oversampling of large firms, in which the existence of
} 
these fields. The following list contains the theoretical constructs and the indicators employed in our investigation.

\section{- Industrial relations:}

Coverage by multi-employer contracts ( $\mathrm{d}$ - dummy variable), existence of a works council (d), trade union density at establishment level, measured as percentage of union members.

- Globalization of the establishment:

percentage of sales exported, most important market (4 categories: 1, if 'regional', 2 if 'national', 3 if 'EU-market', 4 if 'world market'), co-operation with foreign firms (d), firm owns foreign establishments (d), firm is owned by a foreign enterprise (d).

- Technical progress:

$R \& D$ expenditures as a percentage of sales, new patents (d), product innovation (d), process innovation (d), technical level of the machinery (4 categories: 1 if 'newest level', 2 if 'satisfactory', 3 if 'modernization is desired', 4 if 'modernization is necessary').

- Restructuring of the enterprise:

Basic organizational changes, e.g. introduction of profit centres (d), closing of parts of the establishment (d), transfer of parts of the establishment to other company business units (d), foundation of parts of the establishment as separate business unit (d), integration of outside business units (d).

- Additional controls:

firm size, percentage of female employees, existence of training on-the-job financed by the firm, 4 industry dummies ${ }^{3}$.

The indicators used to measure globalization, technical progress and restructuring are far from being perfect. However, their connections with the theoretical items seem to be clear. The proportion of female employees and training on-the-job describe the workplace structure and the productivity. The larger the former the wider the expected differential at the lower end of the wage structure due to incentive arguments. The upper wage spread should rise with an increase of the training because not all employees participate to the same extent. Skilled

industrial relations institutions is more likely.

${ }^{3}$ In the third wave of the panel 14 industries are taken into account. However, some of them are only staffed with one or two establishments. In a preliminary investigation wage differentials with respect to all 14 industries were estimated with food industry as control group. But only those four industries differed considerably in the impact from that of the control group. Therefore, we enlarged the reference sector and use dummies only for those 
workers with high wages have a better chance of further training than others. The industry dummies are additional indicators of the workplace structure.

Estimates of a regression model with the variables listed above give no clear answer to our issue. The estimated coefficients for the three industrial relations variables are all insignificant, and most other regressors are insignificant, too. ${ }^{4}$ Because of strong multicollinearity, the results are not reliable. We attempt to solve this problem by a stepwise procedure. First, we correct the industrial relations indicators from the firm size impact. Another possibility is to consider a restricted sample where firm size varies only within a narrow range. This procedure reduces firm size effects considerably. Yet, we do not follow this approach for two reasons: The sample would be rather small and the impact of industrial relations within middle-sized firms may differ strongly from that in small and large firms. Therefore, no general conclusions would be possible. Next, we reduce the number of explanatory variables and thus the dimension of the design matrix. We conduct a principal component analysis. Finally, we estimate a regression model with factor scores obtained from the principal component analysis, corrected industrial relations' indicators, and some additional variables.

In the first step, the variables indicating coverage, existence of a works council and trade union density have to be adjusted for firm size effects. The method of correction is demonstrated for the coverage variable. At first, the reduced form of a probit model to determine the probability of coverage is estimated within a four-equation model. ${ }^{5}$

$$
\operatorname{Prob}(\text { coverage }=1)_{i}=\Phi\left[\hat{\beta}_{0}+\hat{\beta}_{1} \cdot \text { firmsize }_{i}+\hat{\beta}_{2}\left(\text { firmsize }_{i}\right)^{2}+\hat{\beta}_{k} \cdot X_{i k}\right\rceil=\Phi\left[\text { Probit }_{i}\right] .
$$

The covariates $X_{k}$ incorporate the determinants of coverage (Bellmann, Schnabel, Kohaut 1999), the determinants of works councils (Addison, Schnabel, Wagner 1997), the determinants of trade union density (Klodt, Meyer 1998), and additional regressors of the

industries with a t-value greater than 1: textiles/clothes, chemical industry, quarry industry/glass/ceramics, production of iron-metal goods.

${ }^{4}$ A regression with the wage differential as dependent variable and the above listed independent variables gives the following results with respect to the industrial relations variables (estimated coefficients and t-statistics in parentheses): coverage $2.11(0.40)$; works council $-5.49(-0.90)$; union density $0.02(0.25)$. Only five of the 26 regressors are statistically significant at conventional levels. The complete results are not presented in the tables, but may be obtained from the authors on request.

${ }^{5}$ These refer to the wage differential function, coverage, unions density, and works council. 
wage differential equation estimated in the third step. ${ }^{6}$ From this estimated equation, the probability of coverage is determined excluding the impact of firm size.

$$
\operatorname{Prob}(\text { coverage }=1)_{i}^{\text {corr }}=\Phi\left[\text { Probit }_{i}-\hat{\beta}_{1} \cdot \text { firmsize }_{i}-\hat{\beta}_{2}\left(\text { firmsize }_{i}\right)^{2}\right] .
$$

The same procedure is applied to the variable 'works council'. A probit model with the same right hand side variables is estimated and then the probability that an establishment has a works council is calculated neglecting the firm size effect. Since 'trade union density' is not a dummy variable, we estimate this equation by OLS instead of ML method for the probit model but with the same regressors as the base for the firm size correction.

In the second step we reduce the numerous indicators listed above for globalization, technical progress and restructuring by factor analysis using the principal component method. The number of extracted factors can be determined by the number of factors with an eigenvalue greater than 1 following Kaiser and Dickman (1959). In our data set, five factors fulfil the condition. This model explains $56 \%$ of the variance. Employing the factor scores in the regression model to explain the skilled-unskilled wage differential is statistically unsatisfactory. Only three of five factors show a significant impact on the differential. Additionally, it is difficult to interpret the extracted five factors in the light of the theoretical arguments discussed above.

Interpretation is much easier if the number of factors is restricted to two. Statistically, this restriction can be justified by the scree test (Cattell 1966). According to this concept, factors should not be included in the analysis if their eigenvalues decrease slowly in comparison to factors of higher order. If we follow this approach, only $34 \%$ of the variance are explained. Table 2 presents the matrix of the rotated factor loadings.

Usually, the first factor is a joint factor. According to Table 2, this factor integrates the two theoretical items "globalization" and "technical progress". Six of ten variables of this joint group have loadings on the first factor above 0.5 , a number that is often used as a boundary for interpretation of influence. Two other variables are near this critical value. The finding that globalization and technical progress are integrated into a joint factor corresponds with the difficulty to separate the influence of these items (Leamer 1996, p. 311). The second factor loads on variables characterizing the restructuring of the enterprise, especially closure or outsourcing of parts of the establishment.

\footnotetext{
${ }^{6}$ A complete list is given in Appendix A, excluding the last four variables.
} 
The last step of our investigation focuses on how the adjusted indicators of industrial relations (step 1), the scores of the two extracted factors (step 2), and firm size affect the skilled-unskilled wage differential. The results of the OLS-estimation are presented in Table 3 under the heading of model 1 . In order to check for the relative importance of the several determinants the beta coefficients are displayed. 
Table 2: Rotated factor matrix based on indicators of globalization, technical progress and restructuring of the enterprise, following the varimax criterion, $\mathrm{N}=348$

\begin{tabular}{|c|c|c|}
\hline Variable & Factor 1 & Factor 2 \\
\hline \multicolumn{3}{|l|}{ Globalization of the establishment } \\
\hline Percentage of sales exported & 0.78999 & 0.02784 \\
\hline Most important market, 4 categories & 0.81057 & 0.03266 \\
\hline Co-operation with foreign firms & 0.60112 & 0.17785 \\
\hline Firm owns foreign establishments & 0.59072 & 0.14378 \\
\hline Firm is owned by a foreign enterprise & 0.48887 & -0.02790 \\
\hline \multicolumn{3}{|l|}{ Technical progress } \\
\hline R\&D expenditures as a percentage of sales, 3 categories & 0.69340 & 0.13561 \\
\hline New patents & 0.62923 & 0.19724 \\
\hline Product innovation & 0.49187 & 0.26786 \\
\hline Process innovation & 0.04465 & 0.35044 \\
\hline Technical level of the machinery ${ }^{\mathrm{a}}, 4$ categories & 0.15177 & 0.05617 \\
\hline \multicolumn{3}{|l|}{ Restructuring of the enterprise } \\
\hline Basic organizational changes & 0.17676 & 0.47131 \\
\hline Closing of parts of the establishment & -0.11385 & 0.69197 \\
\hline $\begin{array}{l}\text { Transfer of parts of the establishment to other company } \\
\text { business units }\end{array}$ & 0.02133 & 0.37457 \\
\hline $\begin{array}{l}\text { Foundation of parts of the establishment as a separate } \\
\text { business unit }\end{array}$ & -0.12463 & 0.73341 \\
\hline Integration of outside business units & -0.00193 & 0.10142 \\
\hline
\end{tabular}

${ }^{\mathrm{a}}$ Information is based on Wave 3, which was collected in 1996.

Source: Hannover Panel, Wave 3 and 4.

The regression results of model 1 clearly show that globalization/technical progress, restructuring and firm sizes have a significant impact on the skilled-unskilled wage differential. The signs of the coefficient confirm the expectations. A more intense globalization and skill-biased technical progress, a greater relevance of restructuring or a greater firm size all result in a wider differential. Referring to the industrial relations indicators, the results are mixed. On the one hand, the coefficients for the works council and trade union density are negative, thus, confirming the hypothesis of the dampening impact of industrial relations. Yet, the low t-values indicate that the coefficients are not significantly different from zero. On the other hand, the result for the coverage variable is statistically 
significant, but the coefficient is positive. The adjusted coefficient of determination is rather low. From a theoretical point of view, this is not surprising, since the explanatory factors that were included in the regression are only rough indicators of the marginal productivity at the highest and lowest workplace of an establishment. However, from a statistical point of view the message of Ramsey's RESET is that the null hypothesis of a correct specification is not rejected.

Table 3: Determinants of the skilled-unskilled wage differential in manufacturing establishments in Lower Saxony 1997, N = 315

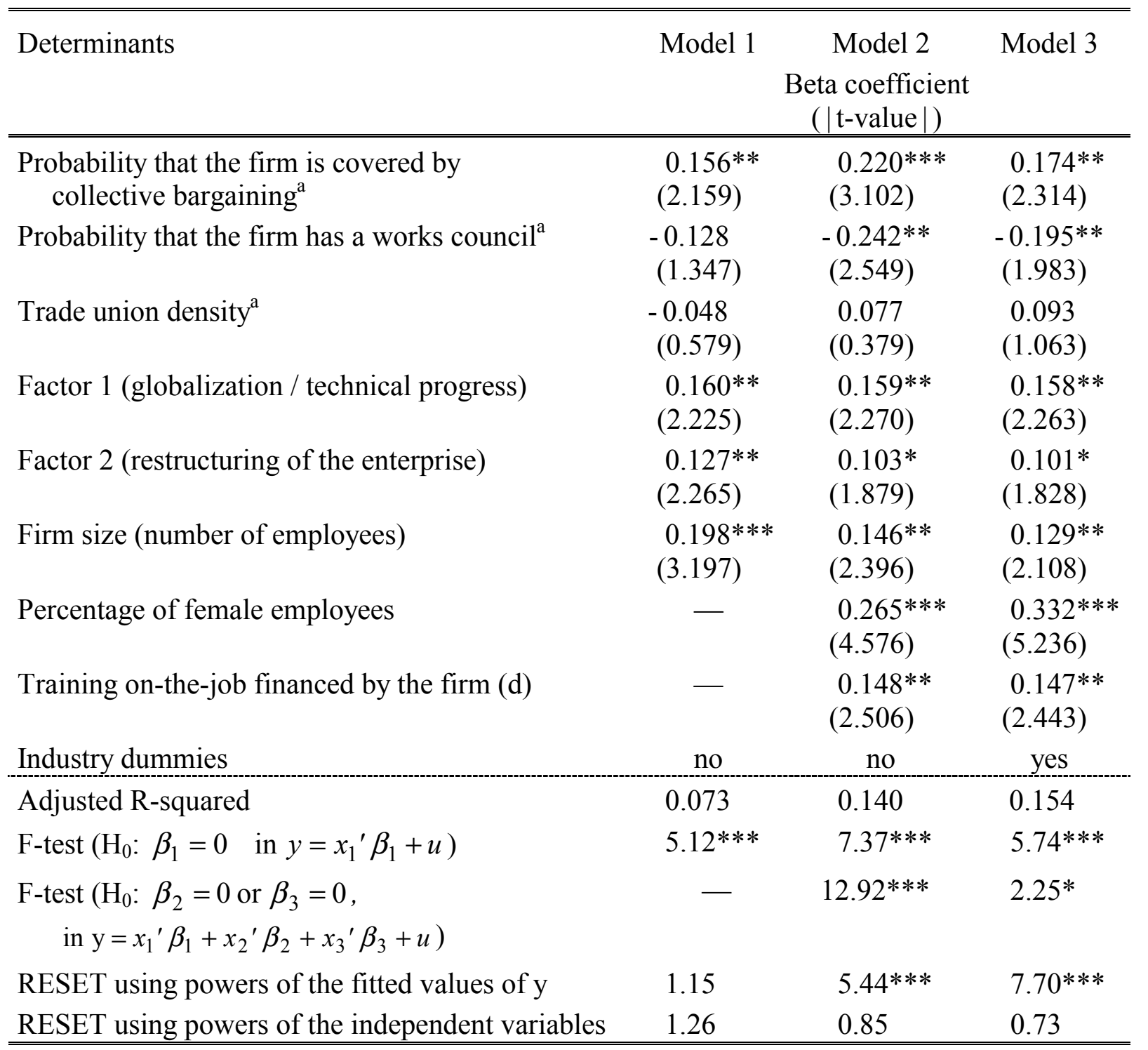

$* / * *$ / *** denote significance at the 0.10 / 0.05 / 0.01 levels, respectively.

${ }^{a}$ The variable is estimated and adjusted by the firm size effects.

Source: Hannover Panel, Wave 3 and 4.

In model 2 further indirect indicators of the work place structure are added: the percentage of female employees and a dummy variable for the existence of further training 
on-the-job within the firm. Both tend to widen the differential as expected. If the former variable rises, the difference between skilled and unskilled wages widens at the lower end, while it is most likely that the latter determinant extends the differential of the better paid workers. Both coefficients are significant at conventional levels and should be included in the estimation according to the F-test, checking for the joint influence of the additional regressors $\left(\mathrm{H}_{0}: \beta_{2}=0\right)$. A look at the results for the core variables of our investigation modifies the findings of the first model. The results regarding coverage are unchanged, i.e. coverage widens the differential significantly, and the trade union density is still without influence. However, the impact of the works council is now negative and statistically significant. If a firm has a works council, the differential is smaller compared to firms without this institution.

Since the first version of the RESET approach of model 2 which uses powers of the fitted values of the endogenous variable rejects the hypothesis of a correct specification, model 3 is augmented by four industry dummies. A look at Table 3, column 3 shows that the values of the estimated beta coefficients change only slightly and the essence of the estimation is still the same. Signs, significance and relative importance of the variables remain unchanged. If an establishment is covered by collective agreements, the skilled-unskilled wage differential is wider than in uncovered firms. The existence of a works council has an opposite effect and the size of trade union density is irrelevant for the differential. ${ }^{7}$ The comparison of the beta coefficients makes obvious that the coverage and the works council effects are stronger than that of most other determinants. Only the percentage of female workers is more_important.

The results of model 3 are satisfactory referring to the statistical indicators, except for the first RESET. This points to omitted variables or non-linear relationships. Augmenting the equation by further available indicators of the workplace structure as for example a team dummy variable or by powers of the independent variables like firm size squared does not change the results substantially. If we use a Box-Cox transformation of the dependent variable and the regressors of model 3 the statistical problem vanishes. Then RESET does not reject the hypothesis of a correct specification. The results regarding signs, significance and relative importance of the variables are the same. The only exception refers to the coefficient of the works council which is no longer statistically significant $(\mid t$-value $\mid=1.277)$.

\footnotetext{
${ }^{7}$ Comparable results arise if we use a modified data set where the small and the big firms are removed from the sample in order to control for the firm size effect and the above analysis is then applied to the middle sized establishments.
} 


\section{$5 \quad$ Summary}

A variety of theoretical approaches predicts that industrial relations institutions tend to induce a compressed wage distribution within firms. However, previous empirical evidence is mixed and thus far no study has singled out the precise mechanisms by which the skilled-unskilled wage differential is affected. According to our results it is important to distinguish between the different elements of industrial relations, since union density, works councils and coverage of collective bargaining have dissimilar impacts. The most remarkable results are the subsequent:

(1) We can not detect any influence of union density on the internal wage structure between skilled and unskilled workers. This seems to be reasonable for the institutional setting of Germany, however, where union representation and activity at the establishment level are weak.

(2) The outcome concerning the impact of the works council on the wage differential conforms to our basic hypothesis. The councils use their better knowledge about the economic situation of the firm to narrow the wages.

(3) Coverage by collective bargaining leads to a widening of the wage structure between skilled and unskilled workers. This result is surprising and defies the demand for a completely decentralized bargaining system. It is concordant with findings from Fitzenberger, Franz (1999) who argue against decentralization. Instead, they favour collective bargaining combined with more flexibility. Insider power is stronger within non-covered establishments and there is a tendency to diminished wage spread.

At odds to theoretical expectations the works council is more influential in compressing the wage differentials within firms than are unions. Commonly, it will be argued that the latter are more interested in redistribution than the former. Our finding gives proof to the opposite. Apparently, for works councils' redistribution is more important than a high wage level for all workers. For a complete picture of the impact of the industrial relations institutions on earnings inequality one must bear in mind that most firms with a works council have coverage at the same time and vice versa. For that reason, the two effects - one negative, the other positive - more or less cancel each other out. The overall effect of the industrial relations institutions on the skilled-unskilled wage differential within firms is, therefore, weak.

Obviously, this result is inconsistent with evidence presented at the macro level. However, it does coincide with an interpretation given recently by Teulings (1998) according to which the wide wage dispersion, as for instance observed in the US, results from different 
payments to the same qualifications in different firms. Unfortunately, our data set does not allow testing this hypothesis directly.

\section{References}

Addison, J. T., Kraft, K. and J. Wagner (1993), German Works Councils and Firm Performance, in: B. E. Kaufman, M. M. Kleiner (eds.), Employee Representation: Alternatives and Future Directions, Madison, Wisconsin: Industrial Relations Research Association, pp. 305 - 35.

Addison, J. T., Schnabel, C. and J. Wagner (1997), On the Determinants of Mandatory Works Councils in Germany, Industrial Relations 36, 419 - 45.

Addison, J. T., Schnabel, C. and J. Wagner (1998), Works Councils in Germany: Their Effects on Firm Performance, University of Lueneburg: mimeo.

Bellmann, L., Kohaut, S. and C. Schnabel (1999), Flächentarifverträge im Zeichen von Abwanderung und Widerspruch,: Geltungsbereich, Einflußfaktoren und Öffnungstendenzen, L. Bellmann and V. Steiner (eds.), Panelanalysen zu Lohnstruktur, Qualifikation und Beschäftigungsdynamik, Beiträge aus der Arbeitsmarkt- und Berufsforschung 229, pp.11 - 40.

Blau, F. D. and L. M. Kahn (1999), Institutions and Laws in the Labor Market, in: O. Ashenfelter, D. Card (eds.), Handbook of Labor Economics, Vol.3A, Amsterdam: Elsevier Science, pp. 1399 - 1461.

Brand, R. et al. (1996), The Hannover Panel, Discussion Paper No. 2 of the "Forschungsstelle Firmenpanel", University of Hannover.

Card, D. (1992), The Effect of Unions on the Distribution of Wages: Redistribution or Relabelling? NBER Working Paper 4195.

Card, D. (1996), Deregulation and Labor Earnings in the Airline Industry, NBER Working Paper 5687.

Cattell, R. B. (1966), The Scree Test for the Number of Factors, Multivariate Behavioral Research 1, 245-276.

DiNardo, J., Fortin, N. M. and T. Lemieux (1996), Labor Market Institutions and the Distribution of Wages, 1973-1992: A Semiparametric Approach, Econometrica 65, pp. $1001-44$.

Fitzenberger, B. (1999), Wages and Employment Across Skill Groups, Heidelberg, New York: Physica-Verlag. 
Fitzenberger, B. and W. Franz (1999), Industry-Level Wage Bargaining: A Partial

Rehabilitation - The German Experience, Scottish Journal of Political Economy 46, pp. $437-57$.

FitzRoy, F. R. and K. Kraft (1985), Unionization, Wages and Efficiency - Theories and Evidence from the U.S. and West Germany, Kyklos 38, pp. 537 - 54.

Flanagan, R. J. (1999), Macroeconomic Performance and Collective Bargaining: An International Perspective, Journal of Economic Literature 37, pp. 1150 -75.

Fortin, N. M. and T. Lemieux (1997), Institutional Changes and Rising Wage Inequality: Is There a Linkage? Journal of Economic Perspectives 11, pp. 75 - 96.

Freeman, R. (1982), Union Wage Practices and Wage Dispersion within the Establishment, Industrial and Labor Relations Review 36, pp. 3 - 21.

Freeman, R. (1993), How Much Has De-Unionization Contributed to the Rise in Male Earnings Inequality? In: S. Danziger, P. Gottschalk (eds.), Uneven Tides: Rising Inequality in America, New York: Russell Sage Foundation, pp. 133 - 63.

Freeman, R. and E. Lazear (1995), An Economic Analysis of Works Councils, in: J. Rogers, W. Streek (eds.), Works Councils: Consultation, Representation and Cooperation in Industrial Relations, Chicago: University of Chicago Press, pp. 27 - 52.

Freeman, R. and J. L. Medoff (1984), What Do Unions Do? New York: Basic Books.

Freeman, R. and R. Schettkat (1999), Skill Compression, Wage Differentials and Employment: Germany vs the US, University of Essex: mimeo.

Gerlach, K., Hübler, O. and W. Meyer (1999), Lohnspreizung durch Globalisierung, technischen Fortschritt, Reorganization oder institutionelle Einflüsse? In: R. Ertel, K. Gerlach, J. Wagner (eds.), Beiträge zur Ökonomie offener Volkswirtschaften, Hannover: NIW Vortragsreihe, Band 12, pp. 149 - 75.

Haskel, J. (1999), Small Firms, Contracting-out, Computers and Wage Inequality: Evidence from UK Manufacturing, Economica 66, pp. 1 -22.

Heywood, J. S., Hübler, O. and U. Jirjahn (1998), Variable Payment Schemes and Industrial Relations: Evidence from Germany, Kyklos 51, pp. 237 - 57.

Hübler, O. and A. König (1998), Produktmarkteinflüsse, Renten und Löhne - Eine semiparametrische Untersuchung, in: K. Gerlach, O. Hübler, W. Meyer (eds.), Ökonomische Analysen betrieblicher Strukturen und Entwicklungen, Frankfurt/New York: Campus, $119-43$.

Jirjahn, U. and T. Klodt (1999), Lohnhöhe, industrielle Beziehungen und Produktmärkte, in: L. Bellmann, S. Kohaut, M. Lahner (eds.), Zur Entwicklung von Lohn und 
Beschäftigung auf der Basis von Betriebs- und Unternehmensdaten, BeitrAB 220, Nürnberg: Institut für Arbeitsmarkt- und Berufsforschung, pp. 27 - 54.

Leamer, E. E. (1996), Wage Inequality from International Competition and Technological Change: Theory and Country Experience, American Economic Review 86, Papers and Proceedings, pp. $309-14$.

Lucifora, C. (1999), Wage Inequalities and Low Pay: The Role of Labour Market Institutions, Palermo: mimeo.

Kaiser, H. F. and K. W. Dickman (1959), Analytic Determination of Common Factors, American Psychologist 14, 425.

Klodt, T. and W. Meyer (1998), Empirical Analysis of Inter-firm Differences in Trade Union Density, Discussion Paper No. 13 of the "Forschungsstelle Firmenpanel”, University of Hannover.

Kraft, K. (1994), Wage Differentials Between Skilled and Unskilled Workers, Weltwirtschaftliches Archiv 130, pp. 329 - 47.

Meyer, W. (1995), Tarifbindung - Ein Hemmnis auf dem Weg zu niedrigeren Lohnkosten? In: U. Schasse, J. Wagner (eds.), Erfolgreich Produzieren in Niedersachsen, Hannover: NIW Vortragsreihe, Band 10, pp. 125 - 43.

Nickell, S. and B. Bell (1996), Changes in the Distribution of Wages and Unemployment in OECD Countries, American Economic Review 86, Papers and Proceedings, pp. 302 08 .

Pischke, J. S. (1998), Ausbildung und Lohnstruktur: Deutschland und die USA in den 80er Jahren, in: B. Gahlen, H. Hesse, H. J. Ramser (eds.), Verteilungsprobleme der Gegenwart. Diagnose und Therapie. Tübingen: Mohr Siebeck, pp. 95 - 117.

Siebert, H. (1997), Labor Market Rigidities: At the Root of Unemployment in Europe, Journal of Economic Perspectives 11, pp. 37 - 54.

Snower, D. (1999), Causes of Changing Earnings Inequality, IZA Discussion Paper No. 29, Bonn.

Teulings, C. N. (1998), Wage Dispersion and Institutions: An Alternative Explanation, Research in Labor Economics 17, pp. 357 - 82.

Vella, F. and M. Verbeek (1998), Whose Wages Do Unions Raise? A Dynamic Model of Unionism and Wage Rate Determination for Young Men, Journal of Applied Econometrics 13, pp. $163-68$. 
Appendix A: List of Predetermined Variables of Equation (1) and (Estimated) Jointly Dependent Variables of Table 3, $\mathrm{N}=315$

\begin{tabular}{|c|c|c|}
\hline Variable & Mean & $\begin{array}{l}\text { Standard } \\
\text { Deviation }\end{array}$ \\
\hline Firm size (number of employees) & 129.13 & 170.97 \\
\hline Firm size squared & 45813.41 & 138454.50 \\
\hline Percentage of female workers & 27.80 & 23.51 \\
\hline Percentage of white collar workers & 26.78 & 17.24 \\
\hline Percentage of part time workers & 6.45 & 9.65 \\
\hline Percentage of shift workers & 15.65 & 23.63 \\
\hline $\begin{array}{l}\text { Percentage of apprentices, temporary workers, and } \\
\text { active owners }\end{array}$ & 10.78 & 12.11 \\
\hline Percentage of workers with variable pay & 20.36 & 33.99 \\
\hline Percentage of sales exported & 14.48 & 22.68 \\
\hline $\begin{array}{l}\text { Technical level of the machinery ( } 1 \text { 'newest level' to } \\
4 \text { 'modernization is necessary') }\end{array}$ & 1.99 & 0.84 \\
\hline Profit situation (1 'very good' to 4 'very bad') & 2.71 & 0.88 \\
\hline Branch plant ( $d=1$, if firm is a branch plant) & 0.10 & 0.30 \\
\hline $\begin{array}{l}\text { Sole-proprietorship ( } d=1 \text {, if firm is owned by a sole } \\
\text { proprietor) }\end{array}$ & 0.05 & 0.21 \\
\hline Firm's age ( $d=1$, if founded before 1960) & 0.68 & 0.47 \\
\hline $\begin{array}{l}\text { Craft establishment ( } d=1 \text {, if firm is member of a craft } \\
\text { guild) }\end{array}$ & 0.81 & 0.40 \\
\hline Teamwork ( $\mathrm{d}=1$, if teams exist) & 0.38 & 0.49 \\
\hline Profit sharing schemes for managers $(d=1$, if present & 0.48 & 0.50 \\
\hline $\begin{array}{l}\text { Profit sharing schemes for employees }(d=1 \text {, if } \\
\text { present) }\end{array}$ & 0.14 & 0.35 \\
\hline $\begin{array}{l}\text { Training on-the-job financed by the firm }(d=1 \text {, if } \\
\text { present) }\end{array}$ & 0.58 & 0.49 \\
\hline Industry dummy textiles/clothes & 0.06 & 0.23 \\
\hline Industry dummy chemical industry & 0.08 & 0.27 \\
\hline Industry dummy quarry industry/glass/ceramics & 0.11 & 0.32 \\
\hline Industry dummy production of iron-metal goods & 0.13 & 0.34 \\
\hline $\begin{array}{l}\text { Probability that the firm is covered by } \\
\text { collective bargaining }^{a}\end{array}$ & 0.69 & 0.23 \\
\hline Probability that the firm has a works council ${ }^{\mathrm{a}}$ & 0.44 & 0.26 \\
\hline Trade union density ${ }^{\mathrm{a}}$ & 30.83 & 17.40 \\
\hline Skilled-unskilled wage differential in percent & 37.04 & 31.29 \\
\hline
\end{tabular}

${ }^{\mathrm{a}}$ The variable is estimated and adjusted by the firm size effects. 


\section{IZA Discussion Papers}

No. Author(s)

81

T. J. Hatton

S. Wheatley Price

82

K. A. Konrad

83

R. Euwals

84

C. M. Schmidt

85

S. Pudney

M. A. Shields

86

J.P. Haisken-DeNew

C. M. Schmidt

87

T. K. Bauer

88

O. Bover

P. Velilla

89

S. Neuman

90

H. Lehmann

J. Wadsworth

91

M. Lechner

92

R. E. Wright

93

M. Lechner

94

M. Eichler

M. Lechner

95
P. Cahuc
A. Zylberberg

96

P. Cahuc

A. Zylberberg
Title

Area

Date

Migration, Migrants and Policy in the United

1

$12 / 99$

Kingdom

Privacy, time consistent optimal labor income

3

$12 / 99$

taxation and education policy

Female Labour Supply, Flexibility of Working Hours, 1 and Job Mobility in the Netherlands

The Heterogeneity and Cyclical Sensitivity of 1 Unemployment: An Exploration of German Labor Market Flows

Gender and Racial Discrimination in Pay and 5/6 Promotion for NHS Nurses

Money for Nothing and Your Chips for Free?

The Anatomy of the PC Wage Differential

Educational Mismatch and Wages in Germany

1

Migration in Spain: Historical Background and 1

Current Trends

Aliyah to Israel: Immigration under Conditions of 1 Adversity

Tenures that Shook the World: Worker Turnover in 4

Russia, Poland and Britain

Identification and Estimation of Causal Effects of 6

Multiple Treatments Under the Conditional

Independence Assumption

The Rate of Return to Private Schooling

5

$12 / 99$

An Evaluation of Public-Sector-Sponsored

6

Continuous Vocational Training Programs in East

Germany

An Evaluation of Public Employment Programmes 6

in the East German State of Sachsen-Anhalt

$12 / 99$

Job Protection, Minimum Wage and Unemployment 3

$12 / 99$

Redundancy Payments, Incomplete Labor

3

$12 / 99$

Contracts, Unemployment and Welfare 
N. Smith

102 B. van der Klaauw J. C. van Ours

\section{K. Brännäs}

G. Brunello

C. Graziano

B. Parigi

106 L. Bellmann

S. Bender

U. Hornsteiner

109 G. J. van den Berg B. van der Klaauw T. Schank
Labor Supply and Matching Rates for Welfare

Characteristics

Estimation in a Duration Model for Evaluating

Different Skill Levels and Firing Costs in a

Matching Model with Uncertainty -

An Extension of Mortensen and Pissarides (1994)

Ownership or Performance: What Determines

Board of Directors' Turnover in Italy?

Job Tenure of Two Cohorts of Young German Men 1979 - 1990: An analysis of the (West-)German Employment Statistic Register Sample concerning multivariate failure times and unobserved heterogeneity

Fast Track or Failure: A Study of the Completion Rates of Graduate Students in Economics

Modeling Financial Incentives to Get Unemployed $3 / 6$

Back to Work

Combining Micro and Macro Unemployment

A Theory of Social Forces and Immigrant Second

A Comparative Look at the Czech Republic

Heterogeneous Labour: New Evidence from a Matched Employer-Employee Data-Set

Do Mandatory Pensions Decrease Household 
114 G. Brunello

A. Medio

115 A. Cigno

F. C. Rosati

116 C. Belzil

117 S. Bender
A. Haas
C. Klose

118 M. A. Shields M. E. Ward

119 A. Lindbeck

D. J. Snower

120 P. T. Pereira

P. S. Martins

121 J. C. van Ours

122 D. Munich

J. Svejnar

K. Terrell

123 J. Hunt

124 R. T. Riphahn

125 F. Büchel

J. R. Frick

126 J. Fersterer

R. Winter-Ebmer

127

M. Karanassou

D. J. Snower

128 O. Ashenfelter

D. Ashmore

O. Deschênes

129 B. R. Chiswick M. E. Hurst

130 G. Brunello

S. Comi

C. Lucifora

131 B. R. Chiswick
An Explanation of International Differences in

2 $2 / 00$

Education and Workplace Training

Why do Indian Children Work, and is it Bad for

3 Them?

Unemployment Insurance and Subsequent Job

3

Duration: Job Matching vs. Unobserved

Heterogeneity

IAB Employment Subsample 1975-1995.

Opportunities for Analysis Provided by the

Anonymised Subsample

Improving Nurse Retention in the British National

Health Service: The Impact of Job Satisfaction on

Intentions to Quit

The Division of Labor and the Market for

Organizations

5

$2 / 00$

Does Education Reduce Wage Inequality?

Quantile Regressions Evidence from Fifteen

European Countries

5

$2 / 00$

Do Active Labor Market Policies Help Unemployed $\quad$ 4/6

Workers to Find and Keep Regular Jobs?

Returns to Human Capital under the Communist

Wage Grid and During the Transition to a Market

Economy

Why Do People Still Live in East Germany?

Rational Poverty or Poor Rationality? The Take-up of Social Assistance Benefits

The Income Portfolio of Immigrants in Germany -

Effects of Ethnic Origin and Assimilation. Or:

Who Gains from Income Re-Distribution?

Smoking, Discount Rates, and Returns to

Education

Characteristics of Unemployment Dynamics: The

Chain Reaction Approach

Do Unemployment Insurance Recipients Actively

Seek Work? Evidence From Randomized Trials in

Four U.S. States

The Employment, Unemployment and

Unemployment Compensation Benefits of

Immigrants

The Returns to Education in Italy: A New Look at the Evidence

Are Immigrants Favorably Self-Selected? An

Economic Analysis
$3 / 00$

$3 / 00$

5

$3 / 00$

$3 / 00$

$3 / 00$

$3 / 00$

$3 / 00$

$3 / 00$

$3 / 00$

$1 / 3 \quad 3 / 00$

1

$3 / 00$ 
Hours and Wages in the Depression: British Engineering, 1926-1938

133 D. N. F. Bell

R. A. Hart

O. Hübler

W. Schwerdt

134 A. D. Kugler

G. Saint-Paul

135 A. Barrett

P. J. O'Connell

136 M. Bräuninger

M. Pannenberg

137 J.-St. Pischke

138 J. Zweimüller

R. Winter-Ebmer

139 R. A. Hart

Y. Ma

140 G. Brunello

S. Comi

141 R. Hujer

M. Wellner

142 J. J. Dolado

F. Felgueroso

J. F. Jimeno

143 P. J. Luke

M. E. Schaffer

144 G. Saint-Paul

145 M.-S. Yun

146 T. K. Bauer

J. P. Haisken-DeNew

147 M. Belot

J. C. van Ours

148 L. Goerke

149 R. Lalive

J. C. van Ours

J. Zweimüller
Paid and Unpaid Overtime Working in Germany and 1 the UK

$3 / 00$

Hiring and Firing Costs, Adverse Selection and

3

$3 / 00$

Long-term Unemployment

Is There a Wage Premium for Returning Irish

1

$3 / 00$

Migrants?

Unemployment and Productivity Growth: An

3

$3 / 00$

Empirical Analysis within the Augmented Solow

Model

Continuous Training in Germany

$3 / 00$

Firm-specific Training: Consequences for Job

$3 / 00$

Mobility

Wages, Hours and Human Capital over the

Life Cycle

Education and Earnings Growth: Evidence from $11 \quad 2 / 5 \quad 4 / 00$

European Countries

The Effects of Public Sector Sponsored Training on

Individual Employment Performance in East

Germany

Explaining Youth Labor Market Problems in Spain: 3

Crowding-Out, Institutions, or Technology Shifts?

$4 / 00$

Wage Determination in Russia: An Econometric 4

Investigation

Flexibility vs. Rigidity: Does Spain have the worst of 1 both Worlds?

Decomposition Analysis for a Binary Choice Model

Employer Learning and the Returns to Schooling

Does the Recent Success of Some OECD

Countries in Lowering their Unemployment Rates

Lie in the Clever Design of their Labour Market

Reforms?

Employment Effects of Labour Taxation in an Efficiency Wage Model with Alternative Budget Constraints and Time Horizons

The Impact of Active Labor Market Programs and Benefit Entitlement Rules on the Duration of Unemployment
7

$4 / 00$

5

$4 / 00$

$4 / 00$

$4 / 00$

$3 \quad 4 / 00$

3

$5 / 00$

$3 / 6 \quad 5 / 00$ 
A Comparison of the Human Capital and Signaling Models: The Case of the Self-Employed and the Increase in the Schooling Premium in the 1980's

Public Employment and Redistributive Politics: $\quad 4$ 
J. FitzGerald

B. Nolan

168 G. S. Epstein

Social Harmony at the Boundaries of the Welfare 3

$6 / 00$

A. L. Hillman

State: Immigrants and Social Transfers

169 R. Winkelmann

Immigration Policies and their Impact: The Case of 1

$7 / 00$ New Zealand and Australia

170 T. K. Bauer

Immigration Policy in Integrated National Economies $\quad 1$

K. F. Zimmermann

171 C. Dustmann

Wages and the Demand for Health - A Life Cycle 5

F. Windmeijer

Analysis

172 D. Card

Reforming the Financial Incentives of the Welfare 3 System

173 D. S. Hamermesh

Timing, Togetherness and Time Windfalls

5

174 E. Fehr J.-R. Tyran

Does Money Illusion Matter? An Experimental 7 Approach

175 M. Lofstrom

Self-Employment and Earnings among High-Skilled 1

176 O. Hübler Immigrants in the United States

Industrial Relations and the Wage Differentials 5 between Skilled and Unskilled Blue-Collar Workers within Establishments: An Empirical Analysis with W. Meyer

Data of Manufacturing Firms

An updated list of IZA Discussion Papers is available on the center's homepage www.iza.org. 